\title{
Managing Ethnic Conflict for Nation Building: A Comparative Study between Malaysia and Nigeria
}

\author{
Suhana $\mathrm{Saad}^{1} \&$ Ray Ikechukwu Jacob ${ }^{2}$ \\ ${ }^{1}$ School of Social, Development \& Environmental Studies, Faculty of Social Sciences \& Humanities, The \\ National University of Malaysia, Bangi, Malaysia \\ ${ }^{2}$ Institute of Ethnic Studies, The National University of Malaysia, Bangi, Malaysia \\ Correspondence: Suhana Saad, School of Social, Development \& Environmental Studies, Faculty of Social \\ Sciences \& Humanities, The National University of Malaysia, 43600 Bangi, Selangor, Malaysia. Tel: \\ 60-12-302-6871. E-mail: suhanasaad@ymail.com
}

Received: January 9, 2012

Accepted: April 3, $2012 \quad$ Published: June 1, 2012

doi:10.5539/ass.v8n7p69

URL: http://dx.doi.org/10.5539/ass.v8n7p69

\begin{abstract}
In several post-colonial countries, nation building has been regarded as one of the most important tasks since World War II. Globally, all aim to achieve unity and harmony among ethnic groups. This effort is not an easy task because of the characteristics of a third world country itself is colored by ethnic diversity. In some countries, the government's efforts to unite the nation face failure due to ethnic and religious conflicts. This study tries to explore how Malaysia and Nigeria manage their ethnic conflicts in term of policy making and also in their respective constitution. Both countries are colonized by Britain and at the same time, hoping for unity for their citizens but the problem they are facing is on how to manage conflicts in order to achieve nation building- Therefore, constitution and policy making must be respected, adhered, and met their citizen needs. Data collection method used in this paper is based on secondary sources from both countries.
\end{abstract}

Keywords: constitution, nation building, Malaysia, Nigeria, ethnic conflict

\section{Introduction}

Ethnic heterogeneity is a pervasive feature of the contemporary world (Ray Ikechukwu Jacob \& Suhana Saad 2011). WALLERSTEIN (1979) asserts that ethnic consciousness and conflict occur when the ethnic groups feel threatened with loss of previously acquired privilege, or conversely feel that it is an opportune moment politically to overcome a longstanding denial of privilege. Their advance of mechanisms and machinations has caused the ethnic tensions and conflicts. According to him, the present manifestation of ethnicity in Africa is an elite and class phenomenon where one elite community feels excluded by another from the control of economic and political power. They then indoctrinate members of their ethnicity to believe that this is a conspiracy by a whole community against another, which should be violently resisted.

Therefore, for many post-colonials, nation building has been regarded as one of the most important tasks since World War II. Despite their aspirations, it has been a sobering experience to see ethnic hostilities and political instability in societies are marked by major cultural cleavage. The evidence of ethnic conflict and political instability is abundant. For instance, in recent decades there have been frequent and almost constant communal, religious, and disputes in Asia, as in Sri Lanka, Myanmar, Pakistan, Bangladesh, India, Philippines and Indonesia. Furthermore, the contemporary politics of Africa such as Sudan, Nigeria, Ghana, Burundi, and Uganda provides the most vivid examples of communal hostilities and political instability.

Malaysia is one of the nation that conditioned by ethnic conflict and politics in their daily live. Like other plural societies, Malaysia has deep vertical cleavages reflecting differences in race, religion, culture, language and even ideology. This country is one of the multi-ethnic societies that achieved some measures of success in managing ethnic relations (In-Won Hwang 2003). The complexities of the Malaysian case stem from the make-up of the population: Malay (58 percent), Chinese ( 24 percent), Indians ( 8 percent), and others (10 percent). Efforts to integrate these diverse groups in the interests of national unity have been, and remain, at the heart of the Malaysian enterprise on nation-building. In comparison, Nigeria is a big country compared to Malaysia. The country itself is Africa's most populous country with more than 250 ethnic groups and comprises of 150 million 
people facing the same ethnic complex as in Malaysia. Referring to PAYNE and NASSAR (2008), there are four main ethnic groups in Nigeria, namely Hausa (21 percent) and Fulani (11 percent) which populate in the north, while Yoruba (21 percent) in the west and Ibo (18 percent) concentrates in the east. Instead of ethnicity complexion, there are also political and religious interference whereby Muslims settle in the northern part and Christians in the southern and eastern region. These four ethnic groups blames each other in terms of petroleum wealthiest controlled by the Ibo, the southeast and the Hausa for the historical and military regimes and yet, the Yoruba for the political and economic problems.

This study tries to explore how these two countries manage their ethnic conflicts in term of constitution and policy making. Constitution plays a vital role in the development of any country and nation. Both countries as mentioned are hoping for national unity for their citizen but the problem is how they are going to manage the ethnic conflict to achieve their respective nation building.

\section{The Constitution, Conflict, and Nation Building}

Can policy makers improve democratic stability in multi-ethnic countries through constitutional design? The design of a constitution and its constitution-making process can play an important role in the political and governance transition. Constitution making is an opportunity element that creates a common vision of the future of a state and a road map on how to get there. The constitution can be partly a peace agreement and partly a framework setting up the rules by which the new democracy will operate. An ideal constitution-making process can accomplish several things. For example, it can drive the transformative process from conflict to peace, seek to transform the society from one that resorts to violence to one that resorts to political means to resolve conflict and shape the governance framework that will regulate access to power and resources all key reasons for conflict (Samuels 2006).

Otherwise, constitutional nation-building has been defined as focusing on enshrining the political values of a political community in a constitutional document that ought to become the focus of nation-building initiatives. In many environments, a strategy of constitutional nation-building deliberately ignoring such elements is unlikely to be successful. In consequence, it is suggested to conceive the constitutional nation building as follows: by incorporating into the constitutional text some of the traditional elements of collective identity such as institutions or symbols, constitutional nation-building is able to filter, formalize, and direct the nation-building process towards democracy and the rule of law. Constitutional nation-building, thus, should make use of the legitimizing power of nationalism rather than attempting to replace it (Armin Von Bogdandy et.al 2005). There are three main tools available to constitutional nation building: the form and procedure of constitution-making itself, the institutional arrangements made in the constitution, and the values and symbols employed or referred to both during the political process and in the final text. Some multiethnic democracies are stable and survive for a long time, others to varying degrees less so. Individual actors who are interested in creating a stable and lasting democratic regime, and have some measure of control over the regime's constitutional design, are necessarily interested in the relationship between specific elements of constitutional design and democratic stability, as well as the factors that condition that relationship (Armin Von Bogdandy et.al 2005).

\section{Brief History and Political Rules: Malaysia and Nigeria}

Malaysia is a federal parliamentary monarchy with multi-party system and the Prime Minister as the head of government. The Malaysian political system refers to all those regulations and practices and the structure of laws that show how the government is run. Malaysian political system has a unique foundation on which the country's machinery functions. The political system of Malaysia is closely modeled by Westminster Parliamentary System, a legacy of British colonial rule. The Constitution came into force on August 27, 1957. A federal constitutional elective monarchy, is nominally headed by the Paramount Ruler or (Yang di-Pertuan Agong), commonly referred to as the King of Malaysia. Selected for a term of five-years from among the nine Sultans (king) of the Malay states, the king also is the leader of the Islamic faith in Malaysia. The other four states, which have titular Governors, do not participate in the selection. The Executive power is vested in the cabinet led by the Prime Minister. The members of the cabinet are all chosen from the members of both houses of Parliaments and are responsible to that body. Malaysia has a bicameral Parliament consisting of the Senate (Dewan Negara) and House of Representatives (Dewan Rakyat). Members of Parliament are elected by popular vote to serve a term of five-years. The legislative power of the political system of Malaysia is divided between the federal and the state legislatures (http://www.123independenceday.com/nigeria/political-systerm.html).

The Malaysian legal system is based on English common law and most of the laws and the constitution are adapted from Indian law. There are the Federal Court, Court of Appeals, High Courts, Session's Courts, Magistrate's Courts, and Juvenile Courts. The judges of the Federal Court are appointed by the paramount ruler on the advice of the 
prime minister. The federal government has authority over external affairs, defense, internal security, justice, federal citizenship, finance, commerce, industry, communications, transportation, and other matters. In Malaysia, the constitution was intended to provide a viable basis for ethnic understanding and good government. Behind it there was a great deal of bargaining, mainly among ethnic groups and political parties. The constitution was drawn up with ethnic considerations explicitly in mind, and some of its clauses lay down basic rules on this (Milne \& Mauzy 1999).

To compare, Nigeria had been ruled by British military for approximately 30 years before getting independence in 1960. It faced lots of violence; including the Nigerian Civil War and corruption during the six different presidents governs the country. In presence, Nigeria practices democracy in their political system which had been established since May 1999. The constitution is made up of three divisions, namely executive, legislature and judiciary. Local government comprises of special powers and laws, meanwhile the National Assembly controls the legislative powers and made up of Senate (109 members elected every four year) and House of Representatives (360 members) (http://www.123independenceday.com/nigeria/political-system.html).

Furthermore, the executive powers are controlled by the President who holds many different roles in the society such as Head of State, Chief Executive of the Federation and the Commander-in-Chief of the Armed Forces of the Federation of Nigeria. Besides,, the judiciary powers comprise of Supreme Court, Court of Appeal and Federal High Court, while every state has their own judiciary systems such as High Court, Sharia Court of Appeal and a Customary Court of Appeal. The National Judicial Council under the Advisory Council will select the Chief Judges for every court. Therefore, the legal system functions to resolve the conflict arises among the citizens on violence and corruption besides shielding the country's right and freedom and control the election process. All in all, Nigeria is facing a tremendous conflict involving power exploitation, political and legal maltreatments. All these abuse results to a continuous conflict of corruption, violence, poverty and others which leading to a catastrophic country http://www.123independenceday.com/nigeria/political-system.html).

\section{Constitution: A Tool to Manage Conflict?}

\subsection{The Case of Malaysia}

The Malaysian Constitution was intended to provide a viable basis for ethnic understanding and good government. Behind it there was a great deal of bargaining, mainly among ethnic groups and political parties. There are two basic points to keep in mind in order to understand the nature and the significance of political process. First, ethnicity is the key and second, the Malays would control the executive. To operate the system of government after independence, the main ethnic groups would have to work together, but the parties had been constructed along the ethnic lines (Milne \& Mauzy 1999). According to In-Won HWANG (2003), the original agreement on the constitutional bargain was a trade-off between Malays and non-Malays, in particular United Malay National Organization (UMNO) and Malaysian Chinese Association (MCA). As a major concession from the Malays, the constitutional package gave non-Malays liberal citizenship regulations. In return, non Malays had to accept the constitutional status of Malay special rights in various fields, such as language, religion, and the status of Malay rules.

The alliance type system resembles the system of elite cooperation and given name of consociationalism. The concept of consociationalism by LIJPHART (1969) contains four key components that would provide a successful political consensus. They are the grand coalition, segmental autonomy, mutual veto and proportionality. First, grand coalition requires power sharing through participation of the representatives of all significant groups in political decision making process. Second, segmental autonomy provides authority to these groups to manage their own internal affairs particularly in two major domains such as education and culture. Third, mutual veto allows each group to protect the disadvantages and advantages which simultaneously promotes equality conditionally to settle sensitive issues. Fourth, proportionality offers each significant group an equal distribution in the electoral system, power sharing, position in public office and resources. However, one of the most important aspects of post 1963 period in Malaysia was the increased politicization of both Malays and Chinese; with the result that segmental leader no longer exercised sufficient authority over their own communities. The gradual polarization of communities during the period of 1963-1969 was heading towards the breakdown of inter-ethnic consociational conflict management. The period from 1963 to 1969 was an important era in the history of Malaysia. In addition to the successful formation of a nation state, it was also marked by the expulsion of Singapore from the Federation and a worsening in race relations. The formation of Malaysia on September 16, 1963, incorporated Sabah, Sarawak, and Singapore. Brunei Darussalam withdrew at the very last moment. The inclusion of Sabah and Sarawak's natives such as the Kadazan, Iban, Dayak, Melanau and Murut expanded the multi-racial composition of the society and they were recognized as bumiputera (sons of the soil). 
On March 5, 1965, however, Singapore was expelled from Malaysia due to problems arising primarily from the proposal to implement the policy of "Malaysian Malaysia" by the Singaporean People's Action Party (PAP), led by LEE Kuan Yew (a former Singapore's Prime Minister). The essence of the idea "Malaysian Malaysia" was that Malaysia was conceived as belonging to Malaysians as a whole and not to any particular community or ethnic. This concept emphasized that public policy should address all Malaysian citizens as equals. This aroused strong communal sentiment in the Chinese community (In-Won Hwang 2003).

On May 13, 1969, racial riots became the single most intensive case of inter-racial violence which Malaysia had undergone since independence. According to Malay perspective, the consociational Alliance regime did not seem to guarantee their intrinsic privileged political hegemony as an indigenous people, even though Malays recognized the superior economic position of non-Malay. The non-Malays especially the Chinese increasingly challenged Malay political hegemony which was an essential part of the Alliance bargain. The consociational Alliance eventually collapsed when escalating Malay grievances over the undermining of their special political position turned into serious inter-racial riots in 1969 (In-Won Hwang 2003). But the new evidence from the British document shown, the riots were not spontaneous acts of communal violence, as is constantly alleged by UMNO, but were fanned by Malay elements, with support from the army and police, wanting to discredit the accommodating Prime Minister and impose a much more rigorous Malay agenda. KUA KIA SOONG in his book Declassified document on the Malaysian Riots of 1969 stated that the goal was to formalise Malay dominance, sideline the Chinese and shelve TUNKU ABDUL RAHMAN Putra Al-Haj ibni Almarhum Sultan Abdul Hamid Shah (the first Malaysia's Prime Minister). The riots were rather a planned attack to oust then TUNKU ABDUL RAHMAN who remained Prime Minister until September 1970 but had little authority anymore. In 1971, he stepped down as President of UMNO after virulent criticism by the Malay "young Turks" headed by MAHATHIR Mohamad, the future Prime Minister. Otherwise, the official report from Malaysian government was that the riots were sparked by opposition parties "infiltrated by Communist insurgents" following huge opposition gains in the election 1969 (Bowring 2007).

As a result, the national principles or Rukunegara was introduced as a tool of unity. Rukunegara presented five principles by which the Malaysian people need to be guided; belief in God; loyalty to king and country; upholding the constitution; rule of law and good behaviour and morality. The national principles are mandatory to public schools to embrace them by requiring all students to state their pledge by reading the national principles in the morning assembly in all public schools. However, the implementations of these principles are no longer in common (Kartini Khalid \& Suhana Saad 2010).

Other government policies were also introduced as an effort to create a positive attitude towards cultural assimilation and the creation of a national culture. Among them was the National Culture Policy (NCP) which was introduced in August 1971 in order to develop a national culture from three elements: the indigenous culture; suitable elements from the non-Malay cultures; and Islam as an important component because it is an official religion based on the constitution (Kartini Khalid \& Suhana Saad 2010).

Beside the national ideology, Malaysia's New Economic Policy (NEP) was first announced in 1970 as the principal policy response to the post-election race riots of May 1969. The NEP had two prongs, namely poverty eradication regardless of race and restructuring society to eliminate the identification of race with economic function. The NEP was supposed to create the conditions for national unity by reducing inter-ethnic resentment due to socio-economic disparities (Jomo 2004; Heng Pek Koon 1997). In general, the Malays were employed predominantly in the agriculture where output per worker was lowest, while the Chinese got the highest and were more easily found in the manufacturing and commercial sector. Employment targets for Malays were based on the premise that their promotion in agriculture should decrease. In most employment sectors, however, the numbers (but not the proportion) of Chinese and Indian would not decrease (Milne \& Mauzy 1999). The impact of the NEP has produced many Malay middle class who hold important positions in the government sector.

The government declared that the NEP's ultimate goal was national unity (In-Won Hwang 2003). The rationale behind the NEP is based on the recognition that national unity in Malaysia is the pre-requisite for development in all aspects of life. Even though the government has strived hard to integrate the society through various visions and ideologies, it is hard to accomplish as the ethnocentrism is still rife among the various ethnics. The inclination to preserve one's traditions has made history, vision and ideologies proposed by the country's leaders simply rhetorical in nature. The adversity was expressed by Tun Dr. MAHATHIR Mohamad, the fourth Prime Minister, who introduced Vision 2020 in 1991. He outlined the country's major challenge in nation building that is to create a Malaysian nation that is united and has similar aspirations, integrate at the territorial level and between ethnics based on equal rights and justice. Vision 2020 stresses development in terms of national unity and social cohesion, economy, social justice, political stability and system of government, quality of life, social 
and spiritual values, national pride and confidence. Vision 2020 sets out not only an economic agenda, social agenda, political agenda, psychological agenda, science and technology agenda but a comprehensive and rounded agenda for the nation (Suhana Saad 2012).

After Vision 2020, Datuk Seri NAJIB Tun Razak the current Prime Minister has introduced the slogan 1Malaysia. The objective is to create oneness or unity within a multi-religious and multi-cultural nation. This slogan means Malaysia embrace a diversity of ethnicity, religions and beliefs and, by being inclusive, build mutual respect and acceptance into a solid foundation of trust and cohesiveness. 1Malaysia is not a new project for nation building. It is built upon the foundations of Federal Constitution, various laws and policies, the Rukunegara, Vision 2020, the National Mission and our view of unity and fairness (Suhana Saad 2012).

1 Malaysia leans against three tenets in enhancing national unity which are: principle of acceptance, principle of national spirit and, principle of social justice. Principle of acceptance means acceptance principle means that even though Malaysians live different lifestyles, practices and culture, we accept each other as loyal friends. The second principle is national spirit regarding to unity concept, nationalism and love for the country have been inculcated early on by past leaders. The third is principle of social justice, each race in this country regardless of background or religion will be accounted for fairly and equitably in their welfare and other social aspects. Through 1Malaysia, each representative needs to transcend racial boundaries and extend their services to other races. Even then, the 1Malaysia which espouses social justice principles is not a platform for any quarter or party to make outrageous claims or demands. The culture of excellence, endurance, humility, acceptance, loyalty, meritocracy, education and integrity are the eight values hem in the 1 Malaysia slogan (Suhana Saad 2012).

Hence, the slogan of 1 Malaysia aspires to strengthen relationships among races. Mutual trust and respect among races needs to exist in order to sow the spirit of unity. People must understand and practice things that place national interests as priority. In creating a unified national race in a multi-ethnic country like Malaysia in this era of globalization, it is imperative that we allow free and fast flow of not just information, capital and people but also value systems, cultures and beliefs from different countries. The ability to build a unified national race depends on the sharing of the values of integrity, ability, dedication and loyalty (Suhana Saad 2012).

Malaysia is a peace country and can manage their ethnic relation very well, but in term of human right aspect, it is still limited. For instance, in 2009, Malaysia is 131 out of the 175 nations which was concerned by the Press Freedom Index. Still, the federal government has refused to take heed and make amendments; instead the atrocities against the civilian continue, in one form or another. On July 9, 2011, NAJIB spared no effort in trying to squash a rally aimed an arguing the government to clean up the electoral system. The 'Walk for Democracy' organized by election watchdog Bersih 2.0 was the trump card needed to awaken the slumbering BN from its comfort zone. But cocky as it has always been, the $\mathrm{BN}$ government refused to learn from the July 9 events and could at best declare both Bersih 2.0 and the rally illegal. More recently, the latest against human rights involved the jet-speed passing of the Peaceful Assembly Bill by which the advocate is a threat to Malaysians' freedom of peaceful assembly and association. So damaging is the threat posed by the Peaceful Assembly Bill that the nation's Bar Council on Nov 29 marched to Parliament as a show of support for the right to peaceful assembly as guaranteed in article 10 of Malaysia's constitution and Article 20 of the Universal Declaration of Human Rights (UDHR). Human Rights Watch director Phil Robertson had lamented: "Malaysia's lawyers are marching out of real concerns that Malaysians' freedoms of peaceful assembly and association are under threat from the proposed law. They have serious proposals to amend the law and the government should give them a serious hearing (Jeswan Kaur 2011)." Besides that, all the state apparatus such as government agency, police, media, Electoral Commission has been utilized for political survival.

\subsection{The Case of Nigeria}

The major contributor to ethnic conflict in Nigeria is what some observers have described as constitutional factor. The focus of this line of argument is that constitutional developments in Nigeria, particularly the colonial constitutions, which tended to engender ethnicism and hinder national integration of particular interest is Arthur Richard Constitution of 1946. This constitution established the first regional governments in Nigeria. Although the constitution achieved the integration of North and South in a common legislative council, it actually brought to force the concept of regionalism (Salawu \& Hassan (2010). According to Adebola Babatunde EKANOLA (2006), there has not been any positive change in this regard since then. Instead, the relationship among the constituent ethnic nationalities and religious groups has worsened drastically in spite of all pretenses to the contrary. Nigeria is not an ethnically homogenous society, having come into being accidentally, as it were, as a product of British imperialism. Today, rather than integrating into a cohesive community with a common sense of national identity and destiny, citizens of Nigeria are returning more and more to primordial affiliations for 
identity, loyalty and security. Instead of forging a united front and presenting a concerted effort to face the challenges of development in an increasingly competitive and globalised world, Nigerians are busy waging ethnic and religious wars, struggling for control over resources, resisting marginalization by dominant ethnic groups, and contending with diverse problems of basic survival.

Independent Nigeria has so far experimented with five constitutions, the 1960, 1963, 1979, 1989 and 1999 constitutions (the 1989 Constitution was not promulgated). The 1999 Constitution has given birth to the Fourth Republic, though with problems for which it faces demands for a revision or amendment. The first two of these constitutions were drawn up during civilian regimes while the last three were made or promulgated during military regimes. Some of the lessons learned by Nigerians during these exercises are enduring. The lessons have been taught and learned that no constitution is perfect; that ineffective constitutions can be amended or completely altered; that constitution - making, whether under a military or civilian regime, calls for adequate consultations and experimentation. Furthermore, as was the experience with the 1963, 1979 and 1999 Constitutions, any constitution that is hurriedly drawn up and not tried, stands the risk of failure when subjected to the pressure of political, legal, economic and social forces in and outside the society .

In managing the law of the country, Nigeria practices and keeps the written constitution which is different from British who regulates unwritten and constitutional principle. Since 1979, Nigeria has sustained 3 different ways of handling the federal, state and local government. Nigeria also has adopted two doctrines in maintaining the legislative power. The first doctrine is adopted from America, namely the Doctrine of Repugnancy. This doctrine has allowed the repulsion of any inconsistent law according to the level of inconsistency by the provisions of the constitution. Then, the second Australian doctrine named Doctrine of Covering the Field states that the Government's Federal can seize any issue which serves the legislative competence and invalidate any state of laws which are incompatible with the federal's legislation (Online Nigeria 2011).

To stress the arising issue, the two Nigerian systems of constitution and politic are on the rock. The constitution itself has been viewed or observed as an experimental way of building up a guided and controlled constitution. This is due to the deficient information and the vaguenes of language use in writing and constructing the black and white constitution. Supposedly, the process of constituting must be standardized and followed certain principles. Thus, the Nigerian Federalism made an attempt to unite the constitutional power by combining two levels of government. This incorporation later become consociational physically and create policies to lessen the ethnic conflicts in community. It is a strategic device to widen the ethnic foundation besides determining the incongruity from the previous authority's patterns. Furthermore, the Nigerian political system has learnt from the country's federal system and adapts their existing consociational modes and policies in dealing with the incongruities. Any new experiment regarding the substantive norms and governance's procedural mechanisms is fully based on elite conformity, coherent and realistic estimate of reciprocal advantage and being benefited by the political class. They were pretending to promote the ethnic awareness which led to a continuing issue for Nigerian federalism. This issue of politicizing the ethnicity for the sake of constitutional experimentation has aggravated the functioning of Nigerian's ethnically based federalism.

In reestablishing the Sharia legal code on October 27, 1999, Zamfara's Governor named Ahmed Sani has also developed new code from personal to criminal matters. This expansion of code has led to a main revolution in term of Nigeria's ethno-religious country. He also launched the Sharia legal code in another 11 northern parts of Nigeria like Sekoto, Kebbi, Niger, Katsina, Kaduna, Kano, Jigawa, Bauchi, Yobe, Gombe and Bomo. Sharia 's change to criminal domain became an arising issue in Nigerian constitution in 1999 which need the constitution to authorize the National Assembly (referring to the case of Sharia Court of Appeal in the Federal Capital City of Abuja) to award supplementary power on the Sharia Court of Appeal (Suberu, 2009).

The Sharia is also an attempt to disorganize the Nigerian government now that a southerner is on the throne. The major causes of conflicts in the northern part of the country which has remained a reoccurring decimal and a standard in Nigeria's body politic is the introduction and imposition of Sharia Law in some northern states in the country. From all intents and purposes, this imposition is a legality and against the secularity of the nation as enshrined in the constitution of the Federal Republic of Nigeria. In Nigeria, this imposition was greeted with widespread violence, riots and clashes. This has, however, created a situation of suspicion, hatred and antagonism between Muslims and non Muslims in the country. The imposition of Sharia increased fanaticism and irredentism on the side of most Islamic adherents and gave legitimacy to Islamic fundamentalism. This was done ostensibly to create appeals and sustain devotion to Islamic tenets, as introduction of the Sharia Law became attractive to almost all the northern states in the country with its disastrous consequences (Ray Ikechukwu Jacon \& Suhana Saad 2011). 
To highlight, according to SAMBO (2003), Sharia was elaborated according to Islamic system of law which fully rooted in four main bases. Firstly, the Qur'an states the emergence or the exposure of Prophet Muhammad existence by God. Secondly is the Sunnah which underlines the Prophet Muhammad and his cohorts' sayings and action as per written in Hadith. Thirdly, the Qiyas explains the process of mutual understanding on what was written in the Qur'an and finally is the Ijma or knowing as the agreeable thoughts by the Islamic scholars. In referring to the reintroduction of Sharia in Kaduna, the journey which started on 14 of December 1999 was totally convoluted as a hidden agenda by the Christians. It happened after the Kaduna State of Assembly sent 11 Muslim members of the committee to collect people's opinions and thoughts towards a must of spreading the Sharia legal system in the state. In return, the Muslims contend that their struggle towards spreading the Sharia is solely Muslim's matter and they also revealed the rebuff of two Christian members in joining the committee. To be brief, the committee sought for public's memorandum start to held their talk or hearing in January 2000 whereby the Christians declined to come beforehand and according to OKPANACHI (2000) they prejudice on Muslims way of getting the memorandum and claimed that the constitution of the Muslims's committee is unlawful. They (the Muslims from various local government), then conferred their findings (memoranda) to the House of Assembly and later both parties (Muslim and Christian) trained their supporters on the disparate of religion basis. In order to overcome the Christians inferiority, they (under the Christian Association of Nigerian) organized a seminar to notify the Christians community on the repercussion of Sharia if the law is being immersed in Christians. Many scholars were involved in the seminar including the secessionist (Chief Chukwuemeka Ojukwu ) who criticized Sharia as a law that will break their privilege and counseled the Igbo to support the Christians in the north. Besides, the Muslims also arranged a program under the National body of Jama'atul Nasir Islam (JNI) and also invited several Christian's speakers. To note, both parties held their seminars or talks in worship centers to serve the Sharia need and yet, the Kaduna's government constituted both Muslims and Christian's committees as formal inter-religious community. This is one of government's solutions to protect their political issue besides appointing equivalent numbers of leaders in the parties (Abdu and Umar, 2002)

SALAWU \& HASSAN (2010) has suggested, for institutionalization of lasting democracy in Nigeria, her ethnic plurality notwithstanding, the wrongs of ethnicism must be righted. This can best be done by good governance. The nation needs a purposeful leadership that has a vision of how to place its citizens at the centre of political project without recourse to ethnic chauvinism and sees acquisition of political power as not an end in itself but a means for serving the collective welfare of its people regardless of their ethnic origin. A leadership that recognizes and respects the many people's that make up this nation, and treats all communities as its constituency thereby allaying the fear of ethnic domination.

According to BEGER (2006), a government crisis in this context is anything that requires the government to drastically change the status quo and shift policy in a new direction. It may be an economic recession that requires privatization, government intervention, or, a war, internal rebellion, etc. They ability of a democratic government to respond effectively to such situations will directly affect the stability of the regime. On one hand, the inability of a government to agree on an effective response to a crisis situation may lead to cabinet and government reshuffling, thus further weakening it, or it may create incentives for some political actors to seek a solution that lies outside of the normal political system, e.g. by staging a coup or seeking secession. As it turns out, there are reasons to believe that some of the constitutional elements of consensus democracy can become obstacles that prevent the government from forming an effective response to the crisis. As a result, consensus democracies might not be the best choice for multiethnic democracies in crisis situations.

\section{Conclusion}

In multi-ethnic countries, government policies to manage conflicts are essential. State apparatus can be used to manage conflicts such as the constitution, laws, government policies, authorities such as police and military, media and others. In the context of managing the conflict to achieve nation building, constitution and policy can be a good medium, and vice versa. In Malaysia, the constitution guarantees freedom to citizens in democracy and the constitution also protects the rights of the ethnic majority and minority. The country can be categorized as a multi-ethnic country with no racial conflict, peacefully. However, human rights record in recent years seems quite bad with some restrictions on freedom of assembly. The question is whether the peace enjoyed by Malaysia is due to the harmonious ethnic relations, religion or because of fear of the ruling regime. Unlike the case of Nigeria, the constitution is linked as a cause of conflict and also the manipulation from the leaders and those who control politics, power and administration. In conclusion, the constitution and state policy is a good tool to manage the conflict but the government must know the limits of their intervention to enable them to manage conflict well. Finally, the government leaders must as well, obey the constitutions themselves. 


\section{References}

Abdu, H., \& Umar, L. (2002). Hope betrayed: a report on impunity and state-sponsored violence in Nigeria. Retrieved December 16, 2011, from http://www.omct.org/files/2002/09/1231/nigeriareport0802.pdf

Adebola Babatunde Ekanola. (2006). National integration and the survival of Nigeria in the 21st century. The Journal of Social, Political and Economic Studies, 31, 279-293.

Armin Von Bogdandy, Stefan Haubler, Felix Hanschmann, \& Raphael Utz. (2005). State-Building, Nation-Building, and Constitutional Politics in Post-Conflict Situations: Conceptual Clarifications and an Appraisal of Different Approaches. In Von Bogdandy, \& R. Wolfrum (Eds.), Max Planck Yearbook of United Nations Law (pp. 579-613).The Netherlands: Koninklijke Brill N.V.

Beger, A. (2006). Constitutional Design in Multiethnic Democracies Regime Stability in Multiethnic Countries during Times of Economic Crisis. Retrieved December 15, 2011, from http://myweb.fsu.edu

Bowring, P. (2007). Digging up the racial past. Retrieved November 28, 2011, from www. Littlespeak.com/The Past/CPast-My-Kiasoong-070517.htm

Heng Pek Koon. (1997). The New Economic Policy and the Chinese community in Peninsular Malaysia. Retrieved October 3, 2011, from http://www.ide.go.jp/English/Publish/Periodicals/De/pdf/97_03_03.pdf

In-Won Hwang. (2003). Personalized Politics: The Malaysian State Under Mahathir. Singapore: Institute of Southeast Asian Studies (Chapter 2).

Jeswan Kaur. (2011). Rising concerns over our human right abuses. Retrieved December 30, 2011 from www.freemalaysiatoday.com

Jomo, K.S. (2004). The New Economic Policy and interethnic relations in Malaysia. Retrieved October 3, 2011, from www.unrisd.org/unrisd/website/document.nsf/(httpPublications)/A20E

Kartini Khalid, \& Suhana Saad. (2010). Power sharing and unity: the politics of alliance in plural society. Managing Success in Unity. Department of National Unity \& Integration: Putrajaya.

Lijphart, A. (1969). Consociational democracy. World Politic, 21, 207-225. http://dx.doi.org/10.2307/2009820

Milne, R.S., \& Mauzy, D.K. (1999). Malaysian politics under Mahathir. London: Routledge, (Chapter 1).

Okpanachi, E. (2000). Ethno-religious identity and conflict in northern Nigeria: understanding the dynamics of Sharia in Kaduna and Kebbi States. Retrieved December 6, 2010, from http://www.irfa-nigeria.org

Online Nigeria. (2011). Political and constitution development since independent. Retrieved November 8, 2011, from http://www.onlinenigeria.com

Payne, J., \& Nassar, R. J. (2008). Politics and Cculture in the Developing World. Pearson Longman: New York (Chapter 12).

Ray Ikechukwu Jacob, \& Suhana Saad. (2011). Ethnic conflict in Nigeria: constitutional law and the dilemma of decision-making. Geografia: Malaysian Journal of Society and Space, 7, 28-36.

Retrieved from http://www.123independenceday.com/nigeria/political-system.html

Salawu, B., \& Hassan A.O. (2010). Ethnic politics and its implications for the survival of democracy in Nigeria. Retrieved November 8, 2011, from http://www.academicjournals.org

Sambo, B. (2003). Sharia and Justice: Lectures and Speeches. Zaria: Sankore Educationers Publishers Ltd (Chapter 4).

Samuels, K. (2006). Post-Conflict Peace-Building and Constitution-Making, Chicago Journal of International Law, 6, 1-20.

Suberu, R. (2009). Religion and institutions: federalism and the management of conflicts over Sharia in Nigeria. Journal of International Development, 21, 547-560. http://dx.doi.org/10.1002/jid.1572

Suhana Saad. (2012). Policies for nation building: the Malaysia's experience. Working paper The $5^{\text {th }}$ Thai-Malaysian International Conference on Southeast Asian Studies: Re-making Historical Memory in Southeast Asia. Mahidol University International College and Universiti Kebangsaan Malaysia. Bangkok, 16-17 Fabruary.

Wallerstein, I. (1979). The capitalist World Economy. Cambridge: Cambridge University Press (Chapter 3). 